\title{
Review Article \\ Role of Membrane Lipid Fatty Acids in Sperm Cryopreservation
}

\author{
Rajes Mandal, Damodar Badyakar, and Jitamanyu Chakrabarty \\ Department of Chemistry, National Institute of Technology, Durgapur, West Bengal 713209, India \\ Correspondence should be addressed to Jitamanyu Chakrabarty; jito19@gmail.com
}

Received 31 July 2014; Accepted 19 October 2014; Published 18 November 2014

Academic Editor: Enzo Vicari

Copyright (C) 2014 Rajes Mandal et al. This is an open access article distributed under the Creative Commons Attribution License, which permits unrestricted use, distribution, and reproduction in any medium, provided the original work is properly cited.

\begin{abstract}
Lipid is an important constituent of cell membrane. Membrane lipid composition of spermatozoa has been correlated to different function. Many researchers have related membrane lipid with survival success after cryopreservation or cold shock. Sperm maturation and acrosome reactions are natural phenomenon, but cryopreservation or cold shock is not. Therefore, sperm cells are not programmed for such change and undergo stress. So the change in membrane lipid composition due to cold shock or cryopreservation may be looked upon as response of spermatozoa to a certain stressed condition. A significant body of research worked on the relationship between membrane lipid and fatty acid composition and ability of cell to tolerate adverse change in temperature. However, as the approach of different research groups was different, it is very difficult to compare the changes. Studies have been done with different species, ejaculated/seminal or epididymal sperm. Lipid analyses have been done with whole cell membrane isolated by different methods. Fatty acids estimated were from whole cell, plasma membrane, head membrane, or phospholipids. The cryopreservation condition, media composition, and diluents/cryoprotectants were also different. At this onset a comprehensive review is needed to cover changes of sperm membrane lipid composition of different species under different cryopreservation conditions.
\end{abstract}

\section{Introduction}

Sperm cell is unique in many respects including structure and function. It is capable of fertilizing egg; it functions in a body different from its origin and gender. Its plasma membrane is also different from most other cell membranes in lipid composition. It contains high amount of polyunsaturated fatty acids (PUFA), especially diPUFA (phospholipids esterified with two PUFA), which is found only in sperm, retina, and certain brain areas $[1,2]$. In particular, PUFA are known to contribute to membrane fluidity and flexibility [3-5]. Membrane lipid composition has been related to their specific functions, because it promotes the creation of microdomains with different fluidity, fusogenicity, and permeability characteristics [2], required for reaching and fusing with the oocyte.

Phospholipids are the most representative lipid fraction of the sperm cell membranes, of which phosphatidylcholine, phosphatidylethanolamine, and sphingomyelin are the major components [6]. Lipid and fatty acid composition of sperm cells differ not only for different animals $[7,8]$ but also for different species [9-12], even for fertile and subfertile population of same species [13-15].

The definite lipid pattern of ejaculated spermatozoa is reached only after epididymal maturation. Plasma membrane lipids of the goat [16], ram [17], and boar [18] spermatozoa have been shown to undergo marked changes during epididymal maturation. The lipid content of whole sperm decreases during epididymal maturation in boar, bull, ram, and rat [19-26], and the cholesterol content decreases in ram, rat, and hamster sperm [27-29]. The cholesterol : phospholipid ratio and concentration of phosphatidylserine, phosphatidylethanolamine, cardiolipin, and ethanolamine plasmalogen decrease in whole ram sperm $[20,27]$. However, increases occur in the amount of the sulphoconjugated sterols in whole hamster and human sperm [28-30] and in unsaturated fatty acids in whole ram sperm [27]. Studies using plasma membrane isolated from boar spermatozoa confirm earlier results with whole sperm that the amount of lipid decreases during epididymal maturation [18]. Although there is a decrease in cholesterol, no significant change is seen in the cholesterol:phospholipid ratio. 
There are also decreases in phosphatidyl ethanolamine and phosphatidyl inositol as well as increases in dermosterol, cholesterol sulphate, phosphatidylcholine, and polyphosphoinositides. There is a decrease in the level of fatty acids and an increase in diacylglycerol but no change in the degree of saturation of fatty acids. Plasma membrane from the anterior head region of ram sperm is particularly rich in ethanolamine and choline phosphoglycerides [17]. The amount of dermosterol and ethanolamine in this region of the plasma membrane decreases whereas the cholesterol: phospholipid ratio increases, during epididymal maturation. The goat sperm plasma membrane is particularly rich in ether lipids phosphatidylcholine and phosphatidylethanolamine. Of all the membrane phospholipids, diacyl phosphatidylethanolamine decreases most strikingly (approx. 65\%) during epididymal maturation of sperm [16].

Changes in the amount and composition of lipids in the plasma membrane of sperm during maturation are thought to explain why ejaculated sperm is more sensitive to cold shock than is testicular sperm $[31,32]$. These changes may also account for the maturation-dependent decrease in charge density at the phospholipid-water interface of ram spermatozoa, detected by electron spin resonance [31] and the decrease in membrane fluidity of bull spermatozoa, seen by fluorescence polarization spectroscopy [33]. Analysis of testicular and ejaculated ram spermatozoa by fluorescence recovery after photobleaching (FRAP) indicates that there are regional differences in the decrease of plasma membrane fluidity [34]. During maturation, the diffusion rate of fluorescent lipid analogue increases in all regions of the sperm except the midpiece.

\section{Changes in Lipid Associated with Cryopreservation}

Cryopreservation affects sperm membrane integrity $[35,36]$. Differences in fatty acid composition and lipid class ratios in spermatozoa among species are important factors in the freezability of the male gametes [37] (the different animals/species and cryopreservation methods are summarized in Table 1). According to Pettitt and Buhr [38] freezing and thawing results in lipid modifications and domains of sperm head plasma membrane react differently to cryopreservation. Furthermore, some studies $[39,40]$ investigated the ability of sperm cells to take up lipid components or fatty acids from the surrounding environment during incubation in vitro [41].

The major problem associated with cryopreservation of sperm cells is the loss of viability using freeze thaw process $[36,42-54]$. Loss of viability is related to membrane leakiness which is induced by sperm phospholipids peroxidation [55, 56]. Different workers have assessed the effect of cryopreservation on sperm membrane fatty acid composition in different species including human.

2.1. Human System. Human sperm cryopreservation is considered to be an important therapeutic option with several practical applications [57, 58]. Analyses of the fatty acid pattern of membrane phospholipids and plasmalogen of human spermatozoa have demonstrated significant levels of PUFAs [59]. The major damage caused during cryopreservation is peroxidation of lipids especially phospholipid bound polyunsaturated fatty acids (PUFAs) [60, 61]. But it is also established that membrane stress rather than lipid peroxidation is related to sublethal cryodamage [62]. The lipid composition of whole spermatozoa is well documented $[7,59]$.

According to Schiller et al. [63], significant changes in lipid composition are associated with freezing/thawing. They suggested that matrix-assisted laser desorption and ionization time-of-flight (MALDI-TOF) mass spectra revealed clear differences between the spermatozoa and the seminal plasma as well as between the native and the cryopreserved spermatozoa. The concentration of 1-stearoyl and 1-palmitoyl-2docosahexaenoyl-sn-glycero-3-phosphocholine shows rapid decrease following cryopreservation. Alvarez and Storey reported a reduction of some fatty acids in human spermatozoa after freezing, with a reduction in PUFA C18:2, C20:3, C20:4, and docosahexaenoic acid (C22:6 n-3; DHA) and an increase of the saturated fatty acid (SFA) C: 16 and SFA C: 18 after freezing [64]. Martínez-Soto et al. [65] confirmed a strong correlation between the fatty acid composition of the human spermatozoa or seminal plasma and the sperm parameters of the samples after thawing. They described a significant correlation between the fatty acid composition of the human spermatozoa or seminal plasma and the sperm parameters of the samples after thawing. PUFA, n-3, and specially DHA are directly correlated with sperm motility and viability after freezing/thawing, and monounsaturated fatty acids (MUFA) were inversely correlated. They also suggested that in the future the fatty acid composition could be used as a predictor of the capacity of cryopreservation of a seminal sample. The susceptibility of spermatozoa to rapid cold shock has been associated with a high ratio of membrane PUFA:SFA and with low levels of cholesterol within the sperm membrane [8]. Lipid diffusion which is reflected in the dynamics of the recovery of the lipid reporter probe ODAF [5-(N-octadecanoyl)aminofluorescein] during FRAP is significantly reduced after thawing in all regions of spermatozoa [66]. Correlation between fluidity and postthaw recoveries of motile and viable spermatozoa showed that there is marked variation between membrane anisotropy values, which were significantly high in cryopreserved samples compared to fresh samples. Furthermore, recovery of motile and viable spermatozoa is strongly correlated to anisotropy of fresh spermatozoa. The higher the membrane fluidity before freezing, the better the response of spermatozoa to cryopreservation [67]. As PUFAs can influence membrane fluidity, it is not surprising to see that membrane fluidity is a predictor of cryogenic success in humans.

2.2. Other Systems. Apart from human spermatozoa other animal systems were also subjected to cryopreservation. The changes associated with lipid composition were studied thoroughly in animal spermatozoa like boar, bovine, marsupials, goat, ram, fowl, and so forth. The ability to cryopreserve spermatozoa from all of the domestic species is challenging. Even 
TABLE 1: Different animals/species and cryopreservation methods.

\begin{tabular}{|c|c|c|}
\hline Animal & Cryopreservation methods & $\begin{array}{c}\text { Reference } \\
\text { number }\end{array}$ \\
\hline \multicolumn{3}{|l|}{ Human } \\
\hline & $\begin{array}{l}\text { Semen was diluted using human sperm preservation medium, TEST-Yolk buffer, or glycerol, } \\
\text { subjected to slow manual cooling in liquid nitrogen }\left(\mathrm{LN}_{2}\right) \text { vapour, and stored in } \mathrm{LN}_{2} \text {. }\end{array}$ & [47] \\
\hline & $\begin{array}{l}\text { The procedure is based on the program of cooling speed doubling: from } 20 \text { to } 5^{\circ} \mathrm{C} \text { at } \\
0.5^{\circ} \mathrm{C} / \mathrm{min} \text {; from } 5 \text { to } 4^{\circ} \mathrm{C} \text { at } 1^{\circ} \mathrm{C} / \mathrm{min} \text {; from } 4 \text { to } 3^{\circ} \mathrm{C} \text { at } 2^{\circ} \mathrm{C} / \mathrm{min} \text {; from } 3 \text { to } 2^{\circ} \mathrm{C} \text { at } 4^{\circ} \mathrm{C} / \mathrm{min} \text {; from } \\
2 \text { to } 1^{\circ} \mathrm{C} \text { at } 8^{\circ} \mathrm{C} / \mathrm{min} \text {; from } 1 \text { to }-80^{\circ} \mathrm{C} \text { at } 10^{\circ} \mathrm{C} / \mathrm{min} \text {. After being held } 10 \text { minutes at the final } \\
\text { temperature, }-80^{\circ} \mathrm{C} \text { then were transferred to } \mathrm{LN}_{2} \text {. }\end{array}$ & {$[62]$} \\
\hline & $\begin{array}{l}\text { Normozoospermic, oligozoospermic, asthenozoospermic, and oligoasthenozoospermic semen } \\
\text { samples were frozen in pellets on the surface of dry ice using a glycerol-based cryoprotectant } \\
\text { with egg yolk. }\end{array}$ & {$[65]$} \\
\hline & $\begin{array}{l}\text { Sperm cells were frozen or cold-shocked by lowering the temp. rapidly from } 37 \text { to } 0^{\circ} \mathrm{C} \text { on } \\
\text { melting ice. }\end{array}$ & {$[66]$} \\
\hline & $\begin{array}{l}\text { Sperm cells were frozen using the programme: from } 20 \text { to }-4^{\circ} \mathrm{C} \text { at } 5^{\circ} \mathrm{C} / \mathrm{min} \text {; from }-4 \text { to }-30^{\circ} \mathrm{C} \\
\text { at } 10^{\circ} \mathrm{C} / \mathrm{min} \text {; from }-30 \text { to }-140^{\circ} \mathrm{C} \text { at } 20^{\circ} \mathrm{C} / \mathrm{min} \text { and then were transferred for storage to } \mathrm{LN}_{2} \text {. }\end{array}$ & {$[67]$} \\
\hline \multicolumn{3}{|l|}{ Ram and goat } \\
\hline Merino rams & $\begin{array}{l}\text { Ejaculates were obtained by electrical stimulation. Semen was also collected from the caput and } \\
\text { cauda epididymis. Spermatozoa were cold-shocked by placing tubes containing the semen held } \\
\text { at } 37^{\circ} \mathrm{C} \text { into a bath at } 0^{\circ} \mathrm{C} \text { for } 10 \mathrm{~min} \text {. }\end{array}$ & {$[20]$} \\
\hline Zandi rams & $\begin{array}{l}\text { The diluted semen was cooled at } 4 \text { to } 5^{\circ} \mathrm{C} \text { for } 2 \mathrm{~h} \text {. Then the samples were placed into the } \mathrm{LN}_{2} \\
\text { vapor at a height of } 4 \mathrm{~cm} \text { above the liquid for } 8 \text { minutes, and then the straws were plunged into } \\
\mathrm{LN}_{2} \text {. }\end{array}$ & {$[80]$} \\
\hline Goat & $\begin{array}{l}\text { Epididymal sperms were cryopreserved using programmable freezer: from } 30 \pm 2^{\circ} \text { to } 5^{\circ} \mathrm{C} \text { at } \\
0.25^{\circ} \mathrm{C} \text { min, from } 5 \text { to }-20^{\circ} \mathrm{C} \text { at } 5^{\circ} \mathrm{C} \text { min, and from }-20 \text { to }-100^{\circ} \mathrm{C} \text { at } 20^{\circ} \mathrm{C} \text { min then transferred } \\
\text { to } \mathrm{LN}_{2} \text {. }\end{array}$ & [81] \\
\hline Goat & Semen was frozen in pellet form on dry ice, and then plunged into $\mathrm{LN}_{2}$. & {$[82]$} \\
\hline Mahabadi bucks & $\begin{array}{l}\text { Ejaculated semen samples were diluted and equilibrated at } 5^{\circ} \mathrm{C} \text { for } 150 \mathrm{~min} \text {. Samples were } \\
\text { frozen in } \mathrm{LN}_{2} \text { vapor, } 4 \mathrm{~cm} \text { above the } \mathrm{L} \text {, for } 7 \mathrm{~min} \text {; subsequently the straws were plunged into } \\
\text { the } \mathrm{LN}_{2} \text { for storage. }\end{array}$ & {$[83]$} \\
\hline Blanca-Celtiberica buck & $\begin{array}{l}\text { Diluted semen was cooled to } 5^{\circ} \mathrm{C} \text { for } 2 \mathrm{~h} \text {, diluted further, and held at } 5^{\circ} \mathrm{C} \text { for } 2 \mathrm{~h} \text {; another } \\
\text { sample was cooled to } 5^{\circ} \mathrm{C} \text { for } 4 \mathrm{~h} \text {; both samples were frozen over } \mathrm{N}_{2} \text { vapour for } 10 \mathrm{~min}, 4 \mathrm{~cm} \\
\text { above } \mathrm{N}_{2} \text { level, plunged, and stored in } \mathrm{LN}_{2} \text {. }\end{array}$ & {$[84]$} \\
\hline $\begin{array}{l}\text { San Clemente bucks } \\
\text { and Tennessee } \\
\text { Myotonic buck }\end{array}$ & $\begin{array}{l}\text { Semen aliquots were cooled on ice for } 1 \mathrm{~h} \text { before transfer to a } 5^{\circ} \mathrm{C} \text { refrigerator and kept for total } \\
\text { of } 1-2 \mathrm{~h} \text {; then extender was added. Fully extended semen was equilibrated at } 5^{\circ} \mathrm{C} \text { for } 2 \mathrm{~h} \text {. Semen } \\
\text { was frozen by suspending straws in } \mathrm{N}_{2} \text { vapour for } 10 \mathrm{~min} \text {, then plunging into } \mathrm{LN}_{2} \text {. }\end{array}$ & {$[85]$} \\
\hline Saanen bucks & $\begin{array}{l}\text { Semen samples were cryopreserved using programmable freezer using a fast freezing curve } \\
\left.\text { (from } 25^{\circ} \mathrm{C} \text { to } 5^{\circ} \mathrm{C} \text { at } 0.25^{\circ} \mathrm{C} / \mathrm{min} \text { and from } 5^{\circ} \mathrm{C} \text { to }-120^{\circ} \mathrm{C} \text { at } 20^{\circ} \mathrm{C} / \mathrm{min}\right) \text { that started at } 28^{\circ} \mathrm{C} \text {. } \\
\text { After reaching a temperature of } 5^{\circ} \mathrm{C}(\sim 80 \mathrm{~min}) \text {, the straws were subjected to an equilibration } \\
\text { time for } 120 \mathrm{~min} \text {. The freezing curve was implemented immediately after the equilibration time } \\
\text { and was sustained until the temperature reached }-120^{\circ} \mathrm{C} \text {, then were placed in } \mathrm{LN}_{2} \text {. }\end{array}$ & [87] \\
\hline $\begin{array}{l}\text { Spanish ibex } \\
\text { (Capra pyrenaica) }\end{array}$ & $\begin{array}{l}\text { The diluted sperm suspension was cooled to } 13^{\circ} \mathrm{C} \text { in a water bath, further cooled to } 5^{\circ} \mathrm{C} \text { over } \\
1 \mathrm{~h} \text {, kept for } 2 \text { more h, and frozen by placing in } \mathrm{N}_{2} \text { vapour } 5 \mathrm{~cm} \text { above the surface of } \mathrm{LN}_{2} \text { for } \\
10 \text { min before plunging into the } \mathrm{LN}_{2} \text {. }\end{array}$ & [102] \\
\hline \multicolumn{3}{|l|}{ Bull } \\
\hline Friesian bull & $\begin{array}{l}\text { Semen was cooled to } 5^{\circ} \mathrm{C} \text { over } 30 \mathrm{~min} \text {, equilibrated for } 6 \mathrm{~h} \text { at } 5^{\circ} \mathrm{C} \text {, and frozen above the surface } \\
\text { of } \mathrm{LN}_{2} \text { (a temperature of }-120^{\circ} \mathrm{C} \text { was attained in } 7 \mathrm{~min} \text { ). }\end{array}$ & [73] \\
\hline Holstein bulls & Semen was cooled to $5^{\circ} \mathrm{C}$ in $1 \mathrm{~h}$; after $4 \mathrm{~h}$ it was pellet-frozen on solid $\mathrm{CO}_{2}$. & {$[74]$} \\
\hline $\begin{array}{l}\text { Holstein, Jersey, and } \\
\text { Guernsey }\end{array}$ & $\begin{array}{l}\text { The semen was cooled immediately after collection to } 15 \text { to } 20^{\circ} \mathrm{C} \text { and held at this temperature } \\
\text { for one-half to one hour; then diluted semen was cooled slowly to a storage temperature } \\
\text { between } 4 \text { and } 7^{\circ} \mathrm{C} \text {. }\end{array}$ & {$[76]$} \\
\hline Prim Holstein & $\begin{array}{l}\text { Electroejaculated semen samples were cooled from } 34 \text { to } 4^{\circ} \mathrm{C} \text { in } 1.5 \mathrm{~h} \text {, held for } 2 \mathrm{~h} \text {, and then } \\
\text { descended in } \mathrm{LN}_{2} \text {. Rate: } 4 \text { to }-10^{\circ} \mathrm{C} \text { at } 0.7^{\circ} \mathrm{C} / 10 \mathrm{~s} ;-10 \text { to }-150^{\circ} \mathrm{C} \text { at } 7^{\circ} \mathrm{C} / 10 \mathrm{~s} \text {. }\end{array}$ & {$[77]$} \\
\hline Holstein & $\begin{array}{l}\text { Fresh sperm samples were cooled to } 4^{\circ} \mathrm{C} \text { and held for } 1 \mathrm{~h} \text { (addition of diluent). Cryostraws were } \\
\text { placed } \sim 5 \mathrm{~cm} \text { above the } \mathrm{LN}_{2} \text { surface for } 10 \mathrm{~min} \text { and then put directly into the } \mathrm{LN}_{2} \text { for storage }\end{array}$ & {$[78]$} \\
\hline
\end{tabular}


TABle 1: Continued.

\begin{tabular}{|c|c|c|}
\hline Animal & Cryopreservation methods & $\begin{array}{c}\text { Reference } \\
\text { number }\end{array}$ \\
\hline Swiss brown bull & $\begin{array}{l}\text { Diluted semen was cooled to } 4-5^{\circ} \mathrm{C} \text { over } 2 \mathrm{~h} \text { and then frozen by being placed into the } \mathrm{LN}_{2} \text { vapor } \\
\text { at a height of } 4 \mathrm{~cm} \text { above the liquid for } 8 \mathrm{~min} \text {; after that, the straws were plunged into } \mathrm{LN}_{2} \text {. }\end{array}$ & [79] \\
\hline \multicolumn{3}{|l|}{ Boar } \\
\hline & $\begin{array}{l}\text { The semen was cooled to } 22^{\circ} \mathrm{C} \text { over } 2 \mathrm{~h} \text { and further cooled to } 5^{\circ} \mathrm{C} \text { over } 3 \mathrm{~h} \text { by placing in a cold } \\
\text { room. Samples were then frozen in } \mathrm{LN}_{2} \text { vapors at } 30^{\circ} \mathrm{C} / \mathrm{min} \text { from } 5^{\circ} \mathrm{C} \text { a final temperature of } \\
-70^{\circ} \mathrm{C} \text {. Then straws were plunged directly into } \mathrm{LN}_{2} .\end{array}$ & {$[38]$} \\
\hline $\begin{array}{l}\text { Norwegian Landrace } \\
\text { and Duroc }\end{array}$ & $\begin{array}{l}\text { The diluted semen was cooled at } 15^{\circ} \mathrm{C} \text { over } 3 \mathrm{~h} \text { and then cooled to } 4^{\circ} \mathrm{C} \text { over } 2 \mathrm{~h} \text { period. Semen } \\
\text { was frozen in a controlled rate freezer for } 9 \text { min. The freezing chamber was precooled to } \\
-100^{\circ} \mathrm{C} \text {. Immediately after the straws were transferred to the chamber it was warmed at } \\
10^{\circ} \mathrm{C} / \text { min to }-70^{\circ} \mathrm{C} \text { and held for } 1 \mathrm{~min} \text { before lowering the temperature to }-120^{\circ} \mathrm{C} \text { at } 50^{\circ} \mathrm{C} / \mathrm{min} \text {. } \\
\text { The straws were held at }-120^{\circ} \mathrm{C} \text { for } 4 \text { min before transferring to } \mathrm{LN}_{2} \text {. }\end{array}$ & [11] \\
\hline $\begin{array}{l}\text { Landrace, Large White, } \\
\text { and commercial hybrids }\end{array}$ & $\begin{array}{l}\text { Semen was cooled at } 15^{\circ} \mathrm{C} \text { for } 3 \mathrm{~h} \text { and was further cooled in a programmable freezer to } 5^{\circ} \mathrm{C} \text { over } \\
90 \mathrm{~min} \text {; samples were cryopreserved using programmable freezer. The freezing chamber was } \\
\text { precooled to }-110^{\circ} \mathrm{C} \text {. Immediately after loading the straws it was warmed at } 45^{\circ} \mathrm{C} / \mathrm{min} \text { to }-60^{\circ} \mathrm{C} \\
\text { and held for } 1 \mathrm{~min} \text { before lowering the temperature to }-130^{\circ} \mathrm{C} \text { at } 20^{\circ} \mathrm{C} / \mathrm{min} \text {. The straws were } \\
\text { plunged into } \mathrm{LN}_{2} \text {. }\end{array}$ & {$[41,90]$} \\
\hline \multicolumn{3}{|l|}{ Marsupial } \\
\hline $\begin{array}{l}\text { Eastern grey kangaroo } \\
\text { (Macropus giganteus) }\end{array}$ & & \\
\hline $\begin{array}{l}\text { Koala } \\
\text { (Phascolarctos cinereus) } \\
\text { Common wombat } \\
\text { (Vombatus ursinus) }\end{array}$ & Epididymal sperms were subjected to cold shock by rapid cooling. & [91] \\
\hline \multicolumn{3}{|l|}{ Canine samples } \\
\hline $\begin{array}{l}\text { Blue fox } \\
\text { (Alopex lagopus) }\end{array}$ & $\begin{array}{l}\text { Semen was cryopreserved in different extenders; FA and sterols of plasma membrane were } \\
\text { analysed. }\end{array}$ & {$[10]$} \\
\hline $\begin{array}{l}\text { Red/silver fox } \\
\text { (Vulpes vulpes) }\end{array}$ & $\begin{array}{l}\text { Cooling at a moderate rate }\left(2-5^{\circ} \mathrm{C} / \mathrm{min} \text { from } 4-5^{\circ} \mathrm{C} \text { to below the freezing point, i.e., from }-7 \text { to }\right. \\
\left.-15 \text { or }-20^{\circ} \mathrm{C}\right) \text { and freezing at a rapid rate from }-20 \text { to }-50 \text { or }-70^{\circ} \mathrm{C} \text {. }\end{array}$ & {$[92,94,95]$} \\
\hline $\operatorname{Dog}$ & $\begin{array}{l}\text { Cooling at a moderate rate }\left(2-5^{\circ} \mathrm{C} / \mathrm{min} \text { from } 4-5^{\circ} \mathrm{C} \text { to below the freezing point, i.e., from }-7 \text { to }\right. \\
\left.-15 \text { or }-20^{\circ} \mathrm{C}\right) \text { and freezing at a rapid rate from }-20 \text { to }-50 \text { or }-70^{\circ} \mathrm{C} \text {. }\end{array}$ & {$[94]$} \\
\hline $\begin{array}{l}\text { Beagle and Golden } \\
\text { Retriever }\end{array}$ & $\begin{array}{l}\text { The samples were maintained at a temperature of } 4^{\circ} \mathrm{C} \text { for total } 1 \mathrm{~h} 30 \mathrm{~min} \text {. Then the canine } \\
\text { semen was frozen in } \mathrm{LN}_{2} \text { vapours }\left(4 \mathrm{~cm} \text { above the level of the } \mathrm{LN}_{2}\right) \text { at }-110^{\circ} \mathrm{C} \text { for } 10 \mathrm{~min} \text { then } \\
\text { immersed vertically in } \mathrm{LN}_{2} \text { for storage at }-196^{\circ} \mathrm{C} \text {. }\end{array}$ & [99] \\
\hline \multicolumn{3}{|l|}{ Elephant } \\
\hline $\begin{array}{l}\text { African Elephant } \\
\text { (Loxodonta Africana) }\end{array}$ & Ejaculated semen samples were stored at $-70^{\circ} \mathrm{C}$ or cryopreserved in $\mathrm{LN}_{2}$. & {$[9]$} \\
\hline \multicolumn{3}{|l|}{$\begin{array}{l}\text { Asian Elephant } \\
\text { (Elephas maximus) }\end{array}$} \\
\hline \multicolumn{3}{|l|}{ Stallion } \\
\hline Andalusian stallions & $\begin{array}{l}\text { The spermatozoa were slowly cooled to } 4^{\circ} \mathrm{C} \text { within } 1 \mathrm{~h} \text { and frozen horizontally in racks placed } \\
4 \mathrm{~cm} \text { above the surface of } \mathrm{LN}_{2} \text { for } 10 \mathrm{~min} \text {, after which they were directly plunged in } \mathrm{LN}_{2} \text {. }\end{array}$ & {$[100,101]$} \\
\hline \multicolumn{3}{|l|}{ Bats/flying fox } \\
\hline \multicolumn{3}{|l|}{$\begin{array}{l}\text { Indian flying-fox } \\
\text { (Pteropus giganteus) }\end{array}$} \\
\hline $\begin{array}{l}\text { Variable flying-fox } \\
\text { (Pteropus hypomelanus) } \\
\text { Grey-headed flying-fox } \\
\text { (Pteropus poliocephalus) } \\
\text { Rodrigues flying-fox } \\
\text { (Pteropus rodricensis) } \\
\text { Large flying-fox } \\
\text { (Pteropus vampyrus) }\end{array}$ & Electroejaculated semen samples were cooled at $50^{\circ} \mathrm{C} / \mathrm{min}$ to $4^{\circ} \mathrm{C}$. & [12] \\
\hline
\end{tabular}


though all of the cells must endure similar physical stresses associated with the cryopreservation processes, sperm from the different species is very different in size, shape, and lipid composition, all of which affect cryosurvival. Thus, when a cryopreservation protocol has been optimized for sperm of one species, it may not be ideal for sperm of the other [68].

2.2.1. Cattle System. Increased concentrations of free cholesterol, free fatty acids, triacylglycerol, and cholesterol ester are associated with decreased sperm motility and fertility [69]. It is also elucidated from the works of bull semen that increased age of bulls has an inverse correlation with the fatty acid composition, especially PUFA and DHA. It is suggested by Argov-Argaman et al. [70] that such alterations might affect the semen's capacity to successfully undergo the cryopreservation procedures, which are widely used in intensive reproduction management.

Egg yolk is widely used and generally accepted as an essential ingredient in diluents employed for the freezing of bovine spermatozoa for use in artificial insemination (AI). It is known to be an efficient protectant of spermatozoa from cooling/thawing [71]. Different forms of lipid extracts confer cryoprotection to frozen spermatozoa [72]. Foulkes and Stewart [73] have demonstrated the maintenance of fertility in spermatozoa frozen in an egg yolk lipoprotein. Irreversible binding of egg yolk lipoprotein and its role in cryopreservation are well elucidated through immunological investigations [72]. Some authors are reluctant in using the whole egg yolk as an extender for cryopreservation as it diminishes the respiration and motility of spermatozoa [7476]. Thus easy techniques for extraction of the essential part, low density lipoprotein (LDL), needed for cryopreservation have been suggested and it is also commented that LDL extenders have improved ability in retaining sperm viability and motility compared to the commercial extenders of egg yolk [77]. A comparative study of egg yolk from five avian species as cryoprotectant showed that pigeon egg yolk has the highest success after thawing in bull sperm [78]. Addition of bull semen extender with n-3 fatty acid and $\alpha$-tocopherol enhanced postthaw sperm characteristics. Before semen freezing, percent DHA was higher in fatty acid treatment than that in the group without fatty acid and decreased significantly in both groups after thawing. A plausible reason for this decrease could be excessive lipid peroxidation during cryopreservation of sperm. This is due to excessive peroxidation as suggested earlier. But addition of $\alpha$-tocopherol is effective and can reverse the effect [79]. Similar works in ram semen also showed similar result with FA and $\alpha$-tocopherol [80]. According to Chakrabarty et al. [81], total lipid and its components, that is, neutral lipids, glycolipids, and phospholipids, decreased significantly after cryopreservation in case of goat semen. Among neutral lipids sterols, steryl esters and 1-O-alkyl-2,3-diacyl glycerol decreased appreciably, while, among phospholipids, major loss was observed for phosphatidylcholine and phosphatidylethanolamine. Unsaturated fatty acids bound to the phospholipids diminished while the percentage of saturated acids increased. Addition of egg yolk plays a major role during the freezing step of goat cryopreservation and the addition of trehalose significantly improved its cryoprotectant activity. Furthermore, neither glycerol nor egg yolk alone could reduce the intact acrosome percentage; however, combination of these two protectants significantly reduces the percentage of intact acrosome spermatozoa [82]. Salmani et al. [83] have suggested the use of soyabeanlecithin which is a suitable plant based cryoprotectant for caprine sperms. The beneficial effects of soyabean-lecithin as a substitute for egg yolk during cryopreservation of goat sperm are established in the works of Jiménez-Rabadán et al., Roof et al., Salmani et al., and Vidal et al. [84-87].

2.2.2. Boar System. The fatty acid composition of boar spermatozoa is interesting, since they contain some $25 \%$ docosapentaenoic acid (C22:5 n-6; DPA) and 30\% DHA [88, 89]. Maldjian et al. [90] have reported a decrease in long chain PUFA and an increase in SFA taken up or passively bound to the spermatozoan membranes. Another distinct change in lipid content was that in the spermatozoan cholesterol level. A study on two different breeds (Norwegian Landrace and Duroc) of boar semen revealed no significant difference between breeds; however, there were significant male-tomale variations within breeds in postthaw percentages of live sperm. The most abundant fatty acids in the plasma membranes from both breeds were palmitic acid (C16:0), stearic acid (C18:0), oleic acid (C18:1 n-9), DPA, and DHA. The ratio of $\sum$ DPA and DHA / $\sum$ all other membrane fatty acids was significantly related to survival rate (plasma membrane integrity) of sperm for both Norwegian Landrace and Duroc boars. Thus Waterhouse et al. [11] concluded that male-tomale differences in sperm survival rate after freezing and thawing may be partly related to the amount of long-chain PUFA in the sperm plasma membranes.

2.2.3. Marsupial System. Marsupial spermatozoa isolated from cauda epididymis had higher levels of long chain PUFA in membrane as compared to spermatozoa isolated from caput epididymis. A study conducted in Kangaroo, Koala, and Wombat confirmed the presence of high PUFA and a high ratio of unsaturated/saturated fatty acids, whereas cholesterol levels are found to be very low in all three species. According to White [8], cold shock resistance is related to high levels of membrane sterols and a low ratio of unsaturated/saturated membrane fatty acids. But the spermatozoa of the koala, common wombat, and Eastern grey kangaroo had very low levels of membrane sterols and very high ratios of unsaturated/saturated membrane fatty acids, but are still resistant to cold shock injury [91].

2.2.4. Other Mammalian Systems. The wild blue or arctic fox (Alopex lagopus), is a canid species that has declining population densities within the northernmost regions of North America and Eurasia $[92,93]$. The causes of the population decline of the wild blue fox within artic areas, particularly in Fennoscandia, have been attributed to urban expansion into the countryside and growing competition with the closely related and widely abundant red fox (Vulpes vulpes). 
Thus artificial insemination (AI) is an efficient tool for increasing the population. While spermatozoa collected from the silver fox can be frozen $[94,95]$, these same protocols and permutations of these protocols have failed to satisfactorily preserve blue fox spermatozoa [94, 95]. Miller et al. [10] carried out experiments in farmed blue fox and silver fox (a colour mutant of red fox) to study the lipid composition in the sperm membrane. It revealed higher ratio of unsaturated/saturated fatty acids and cholesterol in silver fox than blue fox. This may be considered as a key component for the difference in success rates of semen samples after thawing.

The continued loss of natural habitats and the limited ability of wildlife parks and zoos to manage and breed wildlife have created a need for new and improved management and breeding strategies [96]. In case of elephants cryogenic, protocols have successfully preserved spermatozoa from African Elephants (Loxodonta africana), but these protocols and their modified forms failed to preserve spermatozoa of Asian Elephants (Elephas maximus). During cryogenic attempts, the spermatozoa of Asian elephants experience extensive acrosomal damage and thereby become useless for future breeding attempts [97, 98]. In Asian and African elephants, the most abundant fatty acid in spermatozoa membranes was DHA, along with lauric acid (C12:0), myristic acid (C14:0), palmitic acid, stearic acid, and oleic acid [9]. It is been concluded that higher levels of DHA in postthaw samples of African elephants may be beneficial for cryopreservation in comparison to Asian elephant. The differences in fatty acid composition can also be due to nutritional difference and genetic difference in fatty acid metabolism between African and Asian elephants [9]. Similarly bull spermatozoa have been successfully cryopreserved and have high levels of DHA; meanwhile boar spermatozoa with low levels of DHA are difficult to freeze $[7,22]$.

When canine samples were preserved separately with LDL and egg yolk, recovery percentage of sperm motility was higher in samples incubated with LDL. LDL medium also resulted in an improved preservation of spermatozoa during the freezing process in terms of acrosomal integrity, flagellar plasma membrane integrity, and DNA integrity [99].

García et al. [100] also examined the fatty acid and plasmalogen of the phospholipids of the stallion spermatozoa to analyze its relationship with sperm quality after thawing. One of the major drawbacks for the use of frozen thawed semen in equine breeding is the large variation in freezability among stallions. This variability can be explained through susceptibility to lipid peroxidation [101]. As the antioxidant enzymes do not vary considerably among stallions, it is obvious that PUFA and plasmalogens may play a role in such variability.

A study of lipid profile of flying fox (Pteropus) also revealed that stearic acid (C18:0) was the predominant saturated fatty acid and oleic acid (C18:1 n-9) was the predominant unsaturated fatty acid in both acrosomal and plasma membranes. Higher levels of PUFA in the acrosome can attribute to cryogenic success [12]. Chicken egg yolk is the most widely used extender in sperm cryopreservation. But Santiago-Moreno et al. [102] have used Quail egg yolk as an alternative to chicken egg yolk for threatened wild ruminant species, the Spanish ibex. Results showed that this alternative is not a good extender for chicken egg yolk as it provided lower motility and viability.

\section{Scope of Future Work}

Though a good amount of work has been done on the subject discussed above, lack of uniformity provides scope of lot more research work in this field. Change in phospholipids or cholesterol due to cryopreservation drew attention of many researchers as their addition in cryopreservation media provided beneficial effect. Number of works involving change in fatty acids is comparatively very small. Information is wanted with endangered species or animals under captive breeding.

\section{Conflict of Interests}

The authors declare that there is no conflict of interests.

\section{Acknowledgment}

Fellowship of Rajes Mandal by NIT Durgapur is acknowledged.

\section{References}

[1] S. Ladha, "Lipid heterogeneity and membrane fluidity in a highly polarized cell, the mammalian spermatozoon," The Journal of Membrane Biology, vol. 165, no. 1, pp. 1-10, 1998.

[2] S. R. Wassall and W. Stillwell, "Polyunsaturated fatty acidcholesterol interactions: domain formation in membranes," Biochimica et Biophysica Acta: Biomembranes, vol. 1788, no. 1, pp. 24-32, 2009.

[3] J. N. Israelachvili, S. Marcelja, and R. G. Horn, "Physical principles of membrane organization.", Quarterly Reviews of Biophysics, vol. 13, no. 2, pp. 121-200, 1980.

[4] A. D. Fleming and R. Yanagimachi, "Effects of various lipids on the acrosome reaction and fertilizing capacity of guinea pig spermatozoa with special reference to the possible involvement of lysophospholipids in the acrosome reaction," Gamete Research, vol. 4, no. 4, pp. 253-273, 1981.

[5] S. Meizel and K. O. Turner, "Stimulation of an exocytotic event, the hamster sperm acrosome reaction, by cis-unsaturated fatty acids," FEBS Letters, vol. 161, no. 2, pp. 315-318, 1983.

[6] T. Mann and C. Lutwak-Mann, Eds., Male Reproductive Function and Semen, Springer, Berlin, Germany, 1981.

[7] A. Poulos, A. Darin Bennett, and I. G. White, "The phospholipid bound fatty acids and aldehydes of mammalian spermatozoa," Comparative Biochemistry and Physiology Part B: Comparative Biochemistry, vol. 46, no. 3, pp. 541-549, 1973.

[8] I. G. White, "Lipids and calcium uptake of sperm in relation to cold shock and preservation: a review," Reproduction, Fertility, and Development, vol. 5, no. 6, pp. 639-658, 1993.

[9] J. E. Swain and R. R. Miller Jr., "A postcryogenic comparison of membrane fatty acids of elephant spermatozoa," Zoo Biology, vol. 19, no. 5, pp. 461-473, 2000.

[10] R. R. Miller Jr., C. L. Cornett, K. E. Waterhouse, and W. Farstad, "Comparative aspects of sperm membrane fatty acid composition in silver (Vulpes vulpes) and blue (Alopex lagopus) foxes, 
and their relationship to cell cryopreservation," Cryobiology, vol. 51, no. 1, pp. 66-75, 2005.

[11] K. E. Waterhouse, P. O. Hofmo, A. Tverdal, and R. R. Miller Jr., "Within and between breed differences in freezing tolerance and plasma membrane fatty acid composition of boar sperm," Reproduction, vol. 131, no. 5, pp. 887-894, 2006.

[12] D. F. Melville, S. D. Johnston, and R. R. Miller Jr., "Flyingfox (Pteropus spp.) sperm membrane fatty acid composition, its relationship to cold shock injury and implications for cryopreservation success," Cryobiology, vol. 65, no. 3, pp. 224229, 2012.

[13] Y. Aksoy, H. Aksoy, K. Altinkaynak, H. R. Aydin, and A. Özkan, "Sperm fatty acid composition in subfertile men," Prostaglandins Leukotrienes and Essential Fatty Acids, vol. 75, no. 2, pp. 75-79, 2006.

[14] H. Tavilani, M. Doosti, I. Nourmohammadi et al., "Lipid composition of spermatozoa in normozoospermic and asthenozoospermic males," Prostaglandins Leukotrienes and Essential Fatty Acids, vol. 77, no. 1, pp. 45-50, 2007.

[15] N. Am-in, R. N. Kirkwood, M. Techakumphu, and W. Tantasuparuk, "Lipid profiles of sperm and seminal plasma from boars having normal or low sperm motility," Theriogenology, vol. 75, no. 5, pp. 897-903, 2011.

[16] A. P. S. Rana, G. C. Majumder, S. Misra, and A. Ghosh, "Lipid changes of goat sperm plasma membrane during epididymal maturation," Biochimica et Biophysica Acta-Biomembranes, vol. 1061, no. 2, pp. 185-196, 1991.

[17] J. E. Parks and R. H. Hammerstedt, "Development changes occurring in the lipids of ram epididymal spermatozoa plasma membrane," Biology of Reproduction, vol. 32, no. 3, pp. 653-668, 1985.

[18] M. Nikolopoulou, D. A. Soucek, and J. C. Vary, "Changes in the lipid content of boar sperm plasma membranes during epididymal maturation," Biochimica et Biophysica Acta, vol. 815, no. 3, pp. 486-498, 1985.

[19] R. M. C. Dawson and T. W. Scott, "Phospholipid composition of epididymal spermatozoa prepared by density gradient centrifugation," Nature, vol. 202, no. 4929, pp. 292-293, 1964.

[20] P. J. Quinn and I. G. White, "Phospholipid and cholesterol content of epididymal and ejaculated ram spermatozoa and seminal plasma in relation to cold shock," Australian Journal of Biological Sciences, vol. 20, no. 6, pp. 1205-1215, 1967.

[21] D. E. Grogan, D. T. Mayer, and J. D. Sikes, "Quantitative differences in phospholipids of ejaculated spermatozoa and spermatozoa from three levels of the epididymis of the boar," Journal of Reproduction and Fertility, vol. 12, no. 3, pp. 431-436, 1966.

[22] A. Poulos, J. K. Voglmayr, and I. G. White, "Phospholipid changes in spermatozoa during passage through the genital tract of the bull," Biochimica et Biophysica Acta, vol. 306, no. 2, pp. 194-202, 1973.

[23] A. Poulos, P. D. C. Brown-Woodman, I. G. White, and R. I. Cox, "Changes in phospholipids of ram spermatozoa during migration through the epididymis and possible origin of prostaglandin $\mathrm{F}_{2 \alpha}$ in testicular and epididymal fluid," Biochimica et Biophysica Acta: Lipids and Lipid Metabolism, vol. 388, no. 1, pp. 12-18, 1975.

[24] C. Terner, J. MacLaughlin, and B. R. Smith, "Changes in lipase and phosphatase activities of rat spermatozoa in transit from the caput to the cauda epididymidis," Journal of Reproduction and Fertility, vol. 45, no. 1, pp. 1-8, 1975.
[25] R. W. Evans and B. P. Setchell, "Lipid changes in boar spermatozoa during epididymal maturation with some observations on the flow and composition of boar rete testis fluid." Journal of Reproduction and Fertility, vol. 57, no. 1, pp. 189-196, 1979.

[26] M. I. Aveldaño, N. P. Rotstein, and N. T. Vermouth, "Lipid remodelling during epididymal maturation of rat spermatozoa. Enrichment in plasmenylcholines containing long-chain polyenoic fatty acids of the n-9 series," Biochemical Journal, vol. 283, no. 1, pp. 235-241, 1992.

[27] T. W. Scott, J. K. Voglmayr, and B. P. Setchell, "Lipid composition and metabolism in testicular and ejaculated ram spermatozoa.," Biochemical Journal, vol. 102, no. 2, pp. 456-461, 1967.

[28] G. Bleau and W. J. A. VandenHeuvel, "Desmosteryl sulfate and desmosterol in hamster epididymal spermatozoa," Steroids, vol. 24, no. 4, pp. 549-556, 1974.

[29] Y. Legault, M. Bouthillier, G. Bleau, A. Chapdelaine, and K. D. Roberts, "The sterol and sterol sulfate content of the male hamster reproductive tract," Biology of Reproduction, vol. 20, no. 5, pp. 1213-1219, 1979.

[30] G. Lalumiere, G. Bleau, A. Chapdelaine, and K. D. Roberts, "Cholesteryl sulfate and sterol sulfatase in the human reproductive tract," Steroids, vol. 27, no. 2, pp. 247-260, 1976.

[31] R. H. Hammerstedt, A. D. Keith, S. Hay, N. Deluca, and R. P. Amann, "Changes in ram sperm membranes during epididymal transit," Archives of Biochemistry and Biophysics, vol. 196, no. 1, pp. 7-12, 1979.

[32] J. K. Voglmayr, T. W. Scott, B. P. Setchell, and G. M. Waites, "Metabolism of testicular spermatozoa and characteristics of testicular fluid collected from conscious rams.", Journal of Reproduction and Fertility, vol. 14, no. 1, pp. 87-99, 1967.

[33] S. Vijayasarathy and P. Balaram, "Regional differentiation in bull sperm plasma membranes," Biochemical and Biophysical Research Communications, vol. 108, no. 2, pp. 760-769, 1982.

[34] D. E. Wolf and J. K. Voglmayr, "Diffusion and regionalization in membranes of maturing ram spermatozoa," Journal of Cell Biology, vol. 98, no. 5, pp. 1678-1684, 1984.

[35] C. O. Bwanga, "Cryopreservation of boar semen. I: a literature review," Acta Veterinaria Scandinavica, vol. 32, no. 4, pp. 431453, 1991.

[36] P. F. Watson, E. Kunze, P. Cramer, and R. H. Hammerstedt, "A comparison of critical osmolality and hydraulic conductivity and its activation energy in fowl and bull spermatozoa," Journal of Andrology, vol. 13, no. 2, pp. 131-138, 1992.

[37] J. E. Parks and D. V. Lynch, "Lipid composition and thermotropic phase behavior of boar, bull, stallion, and rooster sperm membranes," Cryobiology, vol. 29, no. 2, pp. 255-266, 1992.

[38] M. J. Pettitt and M. M. Buhr, "Extender components and surfactants affect boar sperm function and membrane behavior during cryopreservation," Journal of Andrology, vol. 19, no. 6, pp. 736-746, 1998.

[39] A. R. Neill and C. J. Masters, "Metabolism of fatty acids by bovine spermatozoa," Biochemical Journal, vol. 34, pp. 279-287, 1972.

[40] A. R. Neill and C. J. Masters, "Metabolism of fatty acids by ovine spermatozoa," Journal of Reproduction and Fertility, vol. 34, no. 2, pp. 279-287, 1973.

[41] S. Cerolini, A. Maldjian, F. Pizzi, and T. M. Gliozzi, "Changes in sperm quality and lipid composition during cryopreservation of boar semen," Reproduction, vol. 121, no. 3, pp. 395-401, 2001. 
[42] E. F. Graham and B. O. Crabo, "Some methods of freezing and evaluating human spermatozoa," in The Integrity of Frozen Spermatozoa, pp. 274-304, National Academy of Sciences, Washington, DC, USA, 1976.

[43] K. D. Smith, L. J. Rodriguez-Rigau, and E. Steinberger, "The influence of ovulatory dysfunction and timing of insemination on the success of artificial insemination donor (AID) with fresh or cryopreserved semen," Fertility and Sterility, vol. 36, no. 4, pp. 496-502, 1981.

[44] M. A. Richter, R. V. Haning Jr., and S. S. Shapiro, "Artificial donor insemination: fresh versus frozen semen: the patient as her own control," Fertility and Sterility, vol. 41, no. 2, pp. 277280, 1984.

[45] F. W. Hanson, J. W. Overstreet, and D. F. Katz, "A study of the relationship of motile sperm numbers in cervical mucus 48 hours after artificial insemination with subsequent fertility," American Journal of Obstetrics and Gynecology, vol. 143, no. 1, pp. 85-90, 1982.

[46] G. M. Centola, "Effect of cryopreservation on human sperm motility," Molecular Andrology, vol. 1, no. 4, pp. 399-412, 1989.

[47] G. M. Centola, R. F. Raubertas, and J. H. Mattox, "Cryopreservation of human semen: comparison of cryopreservatives, sources of variability, and prediction of post-thaw survival," Journal of Andrology, vol. 13, no. 3, pp. 283-288, 1992.

[48] J. K. Critser, B. W. Arneson, D. V. Aaker, A. R. Huse-Benda, and G. D. Ball, "Cryopreservation of human spermatozoa. II. Postthaw chronology of motility and of zona-free hamster ova penetration," Fertility and Sterility, vol. 47, no. 6, pp. 980-984, 1987.

[49] J. K. Critser, A. R. Huse-Benda, D. V. Aaker, B. W. Arneson, and G. D. Ball, "Cryopreservation of human spermatozoa. I. Effects of holding procedure and seeding on motility, fertilizability, and acrosome reaction," Fertility and Sterility, vol. 47, no. 4, pp. 656663, 1987.

[50] J. K. Critser, A. R. Huse-Benda, D. V. Aaker, B. W. Arneson, and G. D. Ball, "Cryopreservation of human spermatozoa. III. The effect of cryoprotectants on motility," Fertility and Sterility, vol. 50, no. 2, pp. 314-320, 1988.

[51] E. Z. Drobnis, C. Q. Zhong, and J. W. Overstreet, "Separation of cryopreserved human semen using sephadex columns, washing, or Percoll gradients," Journal of Andrology, vol. 12, no. 3, pp. 201-208, 1991.

[52] R. H. Hammerstedt, J. K. Graham, and J. P. Nolan, "Cryopreservation of mammalian sperm: what we ask them to survive," Journal of Andrology, vol. 11, no. 1, pp. 73-88, 1990.

[53] L. Weidel and G. S. Prins, "Cryosurvival of human spermatozoa frozen in eight different buffer systems," Journal of Andrology, vol. 8, no. 1, pp. 41-47, 1987.

[54] J. W. Overstreet and E. Z. Drobnis, "Sperm transport in the female tract," in Advances in Donor Insemination, C. L. R. Barratt and I. D. Cooke, Eds., Cambridge University Press, Cambridge, UK, 1993.

[55] J. G. Alvarez and B. T. Storey, "Assessment of cell damage caused by spontaneous lipid peroxidation in rabbit spermatozoa," Biology of Reproduction, vol. 30, no. 2, pp. 323-331, 1984.

[56] J. G. Alvarez, J. C. Touchstone, L. Blasco, and B. T. Storey, "Spontaneous lipid peroxidation and production of hydrogen peroxide and superoxide in human spermatozoa. Superoxide dismutase as major enzyme protectant against oxygen toxicity," Journal of Andrology, vol. 8, no. 5, pp. 338-348, 1987.
[57] J. T. Anger, B. R. Gilbert, and M. Goldstein, "Cryopreservation of sperm: indications, methods and results," Journal of Urology, vol. 170, no. 4 I, pp. 1079-1084, 2003.

[58] P. Holoch and M. Wald, "Current options for preservation of fertility in the male," Fertility and Sterility, vol. 96, no. 2, pp. 286290, 2011.

[59] A. Lenzi, M. Picardo, L. Gandini, and F. Dondero, "Lipids of the sperm plasma membrane: From polyunsaturated fatty acids considered as markers of sperm function to possible scavenger therapy," Human Reproduction Update, vol. 2, no. 3, pp. 246256, 1996.

[60] R. J. Aitken, "The role of free oxygen radicals and sperm function," International Journal of Andrology, vol. 12, no. 2, pp. 95-97, 1989.

[61] A. Agarwal, K. Makker, and R. Sharma, "Clinical relevance of oxidative stress in male factor infertility: an update," American Journal of Reproductive Immunology, vol. 59, no. 1, pp. 2-11, 2008.

[62] J. G. Alvarez and B. T. Storey, "Evidence that membrane stress contributes more than lipid peroxidation to sublethal cryodamage in cryopreserved human sperm: glycerol and other polyols as sole cryoprotectant," Journal of Andrology, vol. 14, no. 3, pp. 199-209, 1993.

[63] J. Schiller, J. Arnhold, H. J. Glander, and K. Arnold, "Lipid analysis of human spermatozoa and seminal plasma by MALDI-TOF mass spectrometry and NMR spectroscopy-effects of freezing and thawing," Chemistry and Physics of Lipids, vol. 106, no. 2, pp. 145-156, 2000.

[64] J. G. Alvarez and B. T. Storey, "Evidence for increased lipid peroxidative damage and loss of superoxide dismutase activity as a mode of sublethal cryodamage to human sperm during cryopreservation," Journal of Andrology, vol. 13, no. 3, pp. 232241, 1992.

[65] J. C. Martínez-Soto, J. Landeras, and J. Gadea, "Spermatozoa and seminal plasma fatty acids as predictors of cryopreservation success," Andrology, vol. 1, no. 3, pp. 365-375, 2013.

[66] C. A. James, A. Wolfe, S. Mackie, A. Ladha, and R. Prentice, "Lipid dynamics in the plasma membrane of fresh and cryopreserved human spermatozoa," Human Reproduction, vol. 14, no. 7, pp. 1827-1832, 1999.

[67] M. N. Giraud, C. Motta, D. Boucher, and G. Grizard, "Membrane fluidity predicts the outcome of cryopreservation of human spermatozoa," Human Reproduction, vol. 15, no. 10, pp. 2160-2164, 2000.

[68] P. H. Purdy, "A review on goat sperm cryopreservation," Small Ruminant Research, vol. 63, no. 3, pp. 215-225, 2006.

[69] S. Cerolini, K. A. Kelso, R. C. Noble, B. K. Speake, F. Pizzi, and L. G. Cavalchini, "Relationship between spermatozoan lipid composition and fertility during aging of chickens," Biology of Reproduction, vol. 57, no. 5, pp. 976-980, 1997.

[70] N. Argov-Argaman, K. Mahgrefthe, Y. Zeron, and Z. Roth, "Variation in lipid profiles within semen compartments-the bovine model of aging," Theriogenology, vol. 80, no. 7, pp. 712721, 2013.

[71] P. H. Phillips, "Preservation of bull semen," The Journal of Biological Chemistry, vol. 130, article 415, Abstract, 1939.

[72] A. D. Cookson, A. N. Thomas, and J. A. Foulkes, "Immunochemical investigation of the interaction of egg-yolk lipoproteins with bovine spermatozoa," Journal of Reproduction and Fertility, vol. 70, no. 2, pp. 599-604, 1984. 
[73] J. A. Foulkes and D. L. Stewart, "Fertility of dairy cattle after artificial insemination with semen frozen in a lipoprotein diluent," Journal of Reproduction and Fertility, vol. 51, no. 1, pp. 175-177, 1977.

[74] M. M. Pace and E. F. Graham, "Components in egg yolk which protect bovine spermatozoa during freezing," Journal of Animal Science, vol. 39, no. 6, pp. 1144-1149, 1974.

[75] P. F. Watson, "The interaction of egg yolk and ram spermatozoa studied with a fluorescent probe," Journal of Reproduction and Fertility, vol. 42, no. 1, pp. 105-111, 1975.

[76] R. F. Kampschmidt, D. T. Mayer, and H. A. Herman, "Lipid and lipoprotein constituents of egg yolk in the resistance and storage of bull spermatozoa," Journal of Dairy Science, vol. 36, pp. 733742, 1953.

[77] M. Moussa, V. Martinet, A. Trimeche, D. Tainturier, and M. Anton, "Low density lipoproteins extracted from hen egg yolk by an easy method: cryoprotective effect on frozen-thawed bull semen," Theriogenology, vol. 57, no. 6, pp. 1695-1706, 2002.

[78] L. Su, X. Li, J. Quan et al., "A comparison of the protective action of added egg yolks from five avian species to the cryopreservation of bull sperm," Animal Reproduction Science, vol. 104, no. 2-4, pp. 212-219, 2008.

[79] A. Towhidi and J. E. Parks, "Effect of n-3 fatty acids and $\alpha$ tocopherol on post-thaw parameters and fatty acid composition of bovine sperm," Journal of Assisted Reproduction and Genetics, vol. 29, no. 10, pp. 1051-1056, 2012.

[80] A. Towhidi, S. Zeinoaldini, R. Ardebili, N. Dadashpour Davachi, and A. H. Nasiri, "Combined n-3 fatty acids and $\alpha$ tocopherol supplementation improved the ovine sperm cryosurvival," Iranian Journal of Biotechnology, vol. 11, no. 4, pp. 238243, 2013

[81] J. Chakrabarty, D. Banerjee, D. Pal, J. De, A. Ghosh, and G. C. Majumder, "Shedding off specific lipid constituents from sperm cell membrane during cryopreservation," Cryobiology, vol. 54, no. 1, pp. 27-35, 2007.

[82] E. M.-E. Aboagla and T. Terada, "Effects of egg yolk during the freezing step of cryopreservation on the viability of goat spermatozoa," Theriogenology, vol. 62, no. 6, pp. 1160-1172, 2004.

[83] H. Salmani, A. Towhidi, M. Zhandi, M. Bahreini, and M. Sharafi, "In vitro assessment of soybean lecithin and egg yolk based diluents for cryopreservation of goat semen," Cryobiology, vol. 68, no. 2, pp. 276-280, 2014.

[84] P. Jiménez-Rabadán, M. Ramón, O. García-Álvarez et al., "Effect of semen collection method (artificial vagina vs. electroejaculation), extender and centrifugation on post-thaw sperm quality of Blanca-Celtibérica buck ejaculates," Animal Reproduction Science, vol. 132, no. 1-2, pp. 88-95, 2012.

[85] D. J. Roof, S. Bowley, L. L. Price, and D. J. Matsas, "Comparison of two commercial extenders for cryopreservation of goat semen without sperm washing," Theriogenology, vol. 77, no. 2, pp. 412-420, 2012.

[86] H. Salmani, M. M. Nabi, H. Vaseghi-Dodaran et al., "Effect of glutathione in soybean lecithin-based semen extender on goat semen quality after freeze-thawing," Small Ruminant Research, vol. 112, no. 1-3, pp. 123-127, 2013.

[87] A. H. Vidal, A. M. Batista, E. C. B. da Silva et al., "Soybean lecithin-based extender as an alternative for goat sperm cryopreservation," Small Ruminant Research, vol. 109, no. 1, pp. 47-51, 2013.
[88] P. C. Penny, R. C. Noble, A. Maldjian, and S. Cerolini, "Potential role of lipids for the enhancement of boar fertility and fecundity," Pig News and Information, vol. 25, pp. 119-126, 2000.

[89] J. A. Rooke, C.-C. Shao, and B. K. Speake, "Effects of feeding tuna oil on the lipid composition of pig spermatozoa and in vitro characteristics of semen," Reproduction, vol. 121, no. 2, pp. 315-322, 2001.

[90] A. Maldjian, F. Pizzi, T. Gliozzi, S. Cerolini, P. Penny, and R. Noble, "Changes in sperm quality and lipid composition during cryopreservation of boar semen," Theriogenology, vol. 63, no. 2, pp. 411-421, 2005.

[91] R. R. Miller Jr., C. J. Sheffer, C. L. Cornett, R. McClean, C. MacCallum, and S. D. Johnston, "Sperm membrane fatty acid composition in the Eastern grey kangaroo (Macropus giganteus), koala (Phascolarctos cinereus), and common wombat (Vombatus ursinus) and its relationship to cold shock injury and cryopreservation success," Cryobiology, vol. 49, no. 2, pp. 137148, 2004.

[92] W. Farstad, A. Krogenæs, E. Nagyova, A. L. Hafne, and P. Hyttel, "In vitro techniques in fox reproduction," Livestock Production Science, vol. 36, no. 1, pp. 23-27, 1993.

[93] W. Farstad, "Reproduction in foxes: current research and future challenges," Animal Reproduction Science, vol. 53, no. 1-4, pp. 35-42, 1998.

[94] W. Farstad, "Semen cryopreservation in dogs and foxes," Animal Reproduction Science, vol. 42, no. 1-4, pp. 251-260, 1996.

[95] W. Farstad, J. A. Fougner, and C. G. Torres, "The effect of sperm number on fertility in blue fox vixens (Alopex lagopus) artificially inseminated with frozen silver fox (Vulpes vulpes) semen," Theriogenology, vol. 37, no. 3, pp. 699-711, 1992.

[96] B. L. Lasley, N. M. Loskutoff, and G. B. Anderson, "The limitation of conventional breeding programs and the need and promise of assisted reproduction in nondomestic species," Theriogenology, vol. 41, no. 1, pp. 119-132, 1994.

[97] R. Buice, D. Maloy, C. Wraath, and N. M. Loskutoff, "Effects of various cryoprotectants on epididymal sperm from African elephants (Loxodonta africana)," in Proceedings of the Association of Zoo Veterinary Technicians, Baltimore, Md, USA, 1995.

[98] E. O’Brien, S. Hoffman, T. Schawang et al., "Effects of different cryoprotectants and the short and long term storage of semen from the African elephant," in Proceedings of the 2nd International Elephant Research Symposium, Springfield, Mo, USA, 1997.

[99] D. Bencharif, L. Amirat, M. Anton et al., "The advantages of LDL (Low Density Lipoproteins) in the cryopreservation of canine semen," Theriogenology, vol. 70, no. 9, pp. 1478-1488, 2008.

[100] B. M. García, L. G. Fernández, C. O. Ferrusola et al., "Fatty acids and plasmalogens of the phospholipids of the sperm membranes and their relation with the post-thaw quality of stallion spermatozoa," Theriogenology, vol. 75, no. 5, pp. 811-818, 2011.

[101] C. Ortega Ferrusola, L. González Fernández, J. M. Morrell et al., "Lipid peroxidation, assessed with BODIPY-C 11, increases after cryopreservation of stallion spermatozoa, is stallion-dependent and is related to apoptotic-like changes," Reproduction, vol. 138, no. 1, pp. 55-63, 2009.

[102] J. Santiago-Moreno, M. A. Coloma, A. Toledano-Díaz et al., "A comparison of the protective action of chicken and quail egg yolk in the cryopreservation of Spanish ibex epididymal spermatozoa," Cryobiology, vol. 57, no. 1, pp. 25-29, 2008. 


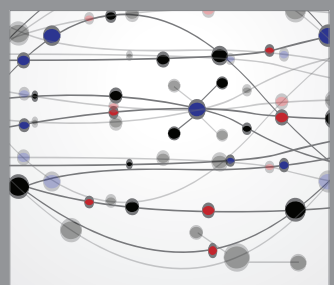

The Scientific World Journal
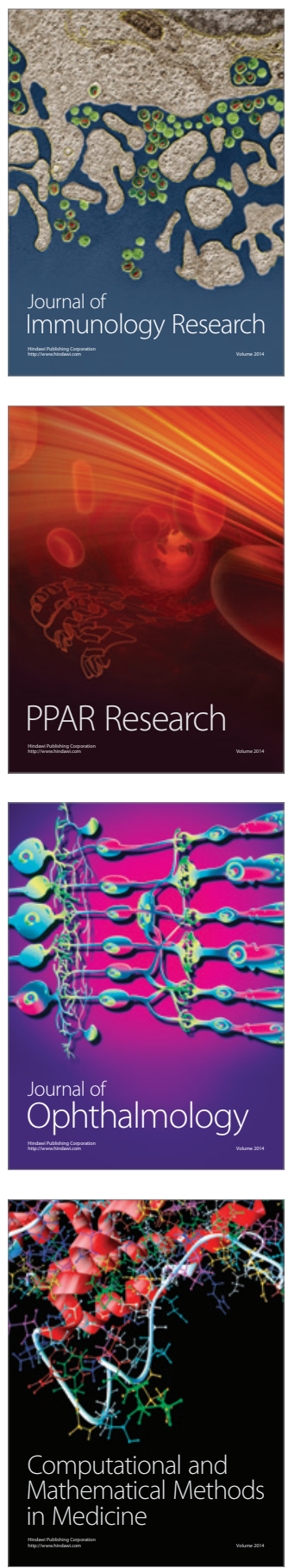

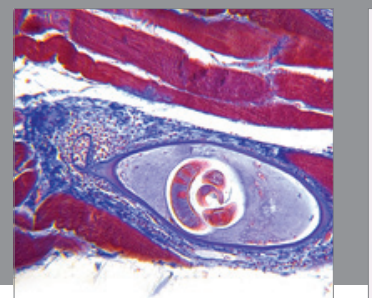

Gastroenterology

Research and Practice
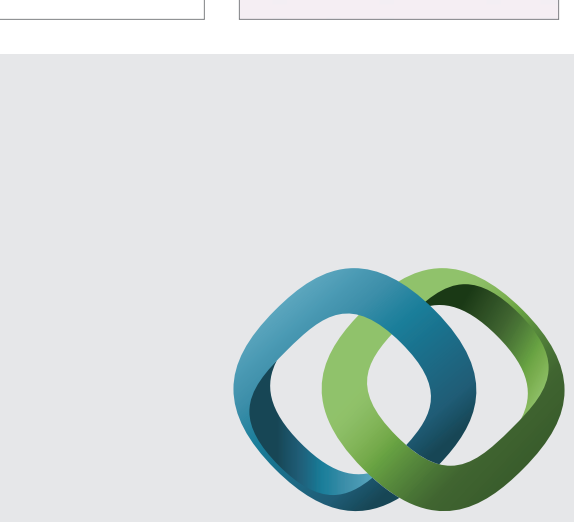

\section{Hindawi}

Submit your manuscripts at

http://www.hindawi.com
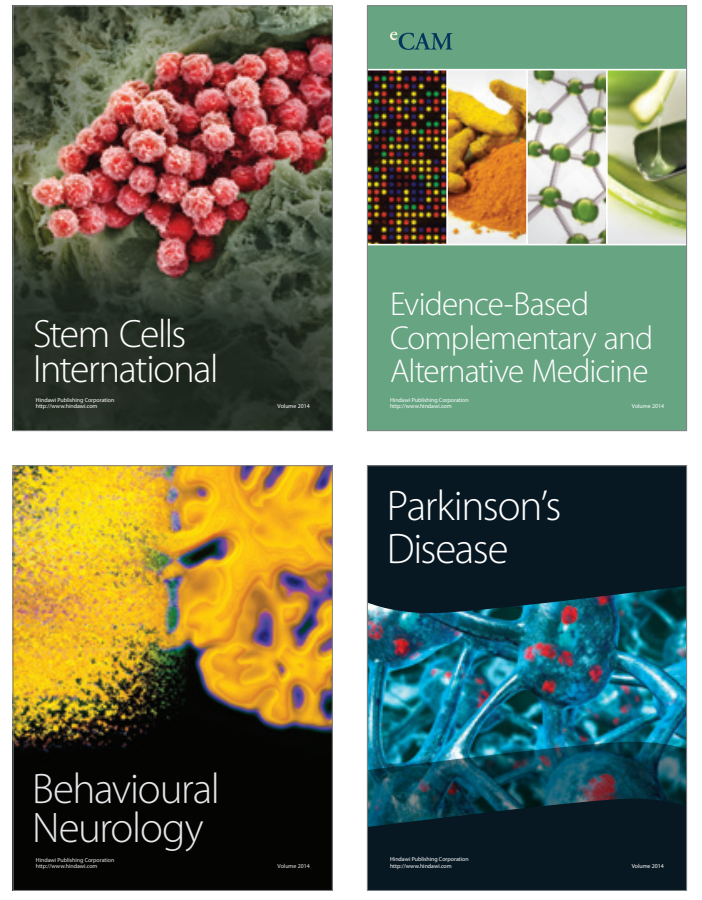
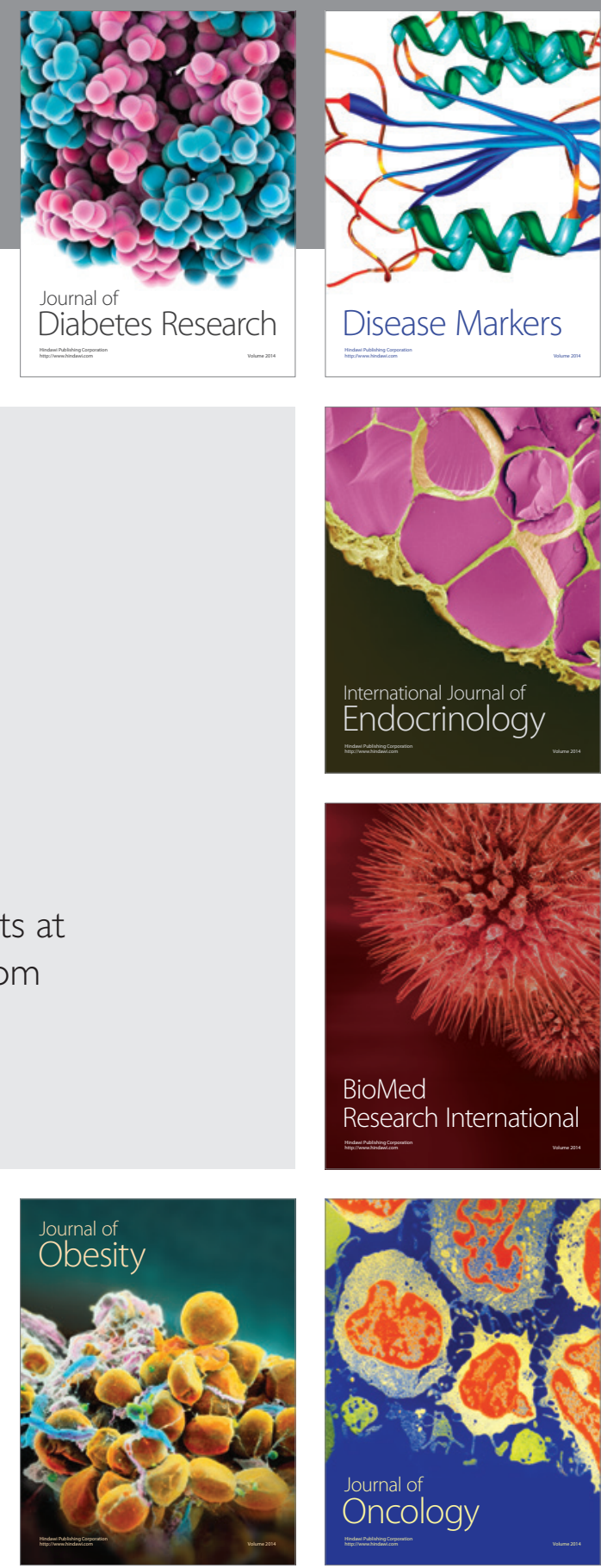

Disease Markers
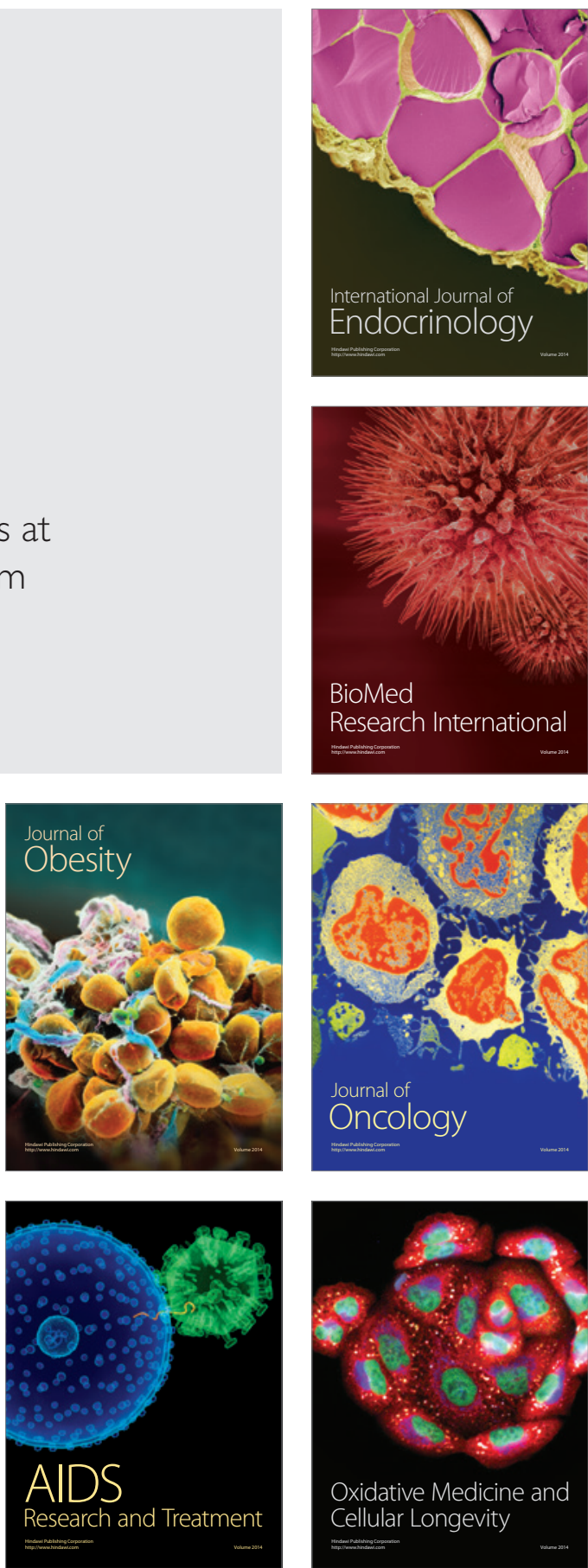